\title{
Kvalita výuky cizích jazyků - vývoj a pilotáž pozorovacího nástroje ${ }^{1}$
}

\section{Teaching quality of foreign language - development and pilot study of observation instrument}

\author{
Pavel Zlatníček
}

\begin{abstract}
Abstrakt: Článek predstavuje autorův výzkum v oblasti kvality výuky cizího jazyka v rámci disertační práce. Ta se zabývá výzkumem kvality výuky z hlediska (a) motivování; (b) klimatu podporujícího učení; (c) práce s časem; (d) orientace na cíle; (e) učitelova projevu. V rámci článku jsou predstaveny cíle výzkumu, přistupy výzkumu, pozorovací nástroj kvality výuky, který bude využit při výzkumu v autorově disertační práci a dosavadní výsledky pilotáže.
\end{abstract}

Klíčová slova: kvalita, kvalita výuky, kvalita výuky cizího jazyka, oblasti kvality výuky, indikátory kvality výuky.

\begin{abstract}
This paper deals with a research in area of teaching quality of foreign language within framework of dissertation thesis, which is focused on research of teaching quality from viewpoint: (a) motivation; (b) a supportive classroom climate; (c) use of learning time; $(d)$ goal orientation; (e) teacher's speech. In frame of this paper are the aim of research, accesses of research, observation instrument for teaching quality and first results of pilot study introduced.
\end{abstract}

Keywords: quality, teaching quality, quality of foreign language teaching, areas of teaching quality, indicators of teaching quality.

\section{1 Úvod}

Kvalita výuky ve smyslu vědeckého konstruktu, kolem něhož by bylo možno rozvinout empirický výzkum, není v České republice dosud hlouběji rozpracována. Chybí zejména systematický výzkum kvality, jdoucí napřič kurikulem školního vzdělávání a zohledňující odlišnosti vyplývající ze specifické povahy učiva $v$ různých vyučovacích předmětech (srov. Janík et al., 2010, s. 23).

Z přehledu odborné literatury vyplývá, že výzkum různých aspektů kvality výuky je doménou především př́rodovědných (matematika, fyzika) a už méně jazykových nebo společenskovědních a estetických předmětů (Zlatníček, Ducháčková, \& Janík, 2010, s. 33).

Ze zjištění, že pedagogický výzkum nevěnuje problematice kvality výuky cizích jazyků tak velkou pozornost, vyplývá potřeba zkoumat tuto oblast vzdělávání. Výzkum skýtá ale i problémy $\mathrm{v}$ tom, že se jedná o oblast, která není zdaleka tak dobře výzkumně pokryta jak $\mathrm{v}$ zahraničním, tak v českém prostředí. V zahraničí byla v rámci výzkumu kvality výuky cizího jazyka významným příspěvkem videostudie DESI (Klieme et al., 2008), která je

\footnotetext{
${ }^{1}$ Př́íspěvek vznikl v rámci řešení projektu MUNI/A/1020/2010 Nástroje pro monitoring a evaluaci kvality ve vzdělávání (NAME 2011). Jeho prezentace na konferenci byla podpořena Stipendijním fondem PdF MU.
} 
v oblasti tohoto oborově specifického výzkumu první. V českém prostředí se problematikou výzkumu kvality výuky cizích jazyků v rámci videostudie doposud nezabýval nikdo.

Článek navazuje na výzkum autora $\mathrm{v}$ oblasti kvality výuky cizího jazyka $\mathrm{v}$ rámci jeho disertační práce. Ta se zabývá výzkumem kvality výuky cizího jazyka z hlediska (a) motivování; (b) klimatu podporujícího učení; (c) práce s časem; (d) orientace na cíle; (e) učitelova projevu. Tyto oblasti jsou v odborné literatuře popsány oborově obecnými a oborově specifickými charakteristikami kvality výuky. V rámci článku jsou prezentovány cíle a přistupy výzkumu, pozorovací nástroj, který bude využit při výzkumu v autorově disertační práci a také dosavadní výsledky pilotáže.

\section{Cíle a přístup výzkumu}

Cílem výzkumu bylo sestavit na základě rešerše empirických výzkumů v českém (Žák, 2006) a zahraničním (Helmke et al., 2007; Klieme et al., 2008; Seidel et al., 2003) prostředí pozorovací nástroj kvality výuky cizího jazyka, který se bude vztahovat na oblasti: (a) motivování; (b) klimatu podporujícího učení; (c) práce s časem; (d) orientace na cíle; (e) učitelova projevu. Při hledání vhodného nástroje pro pozorování výuky ve vytyčených oblastech kvality výuky se vycházelo ze zkušeností Helmkeho (2009), Kliemeho et al. (2006) a Hugenerové (2006). Uvedení autoři doporučují pro posuzování kvality výuky využívat pozorovací nástroje s ratingovým systémem. Pomocí takových systémů posuzují obvykle dva na sobě nezávislí pozorovatelé jednoznačnost konkrétních charakteristik kvality ve výuce (např. jasnost). Podle Kliemeho et al. (2006) a Helmkeho et al. (2007) by měly být ratingy aplikovány především na celé vyučovací jednotky. Tak tomu je i u vlastního představovaného pozorovacího nástroje kvality výuky cizího jazyka, který je představen v dalším textu.

\section{Tvorba pozorovacího nástroje kvality výuky}

Pro návrh vlastního pozorovacího nástroje byly inspirací zdroje z české (Žák, 2006) a především ze zahraniční literatury (Helmke et al., 2007; Klieme et al., 2008; Seidel et al., 2003). Uvedení autoři vypracovali ratingové systémy, které jsou inspirací pro vývoj vlastního pozorovacího nástroje $\mathrm{v}$ rámci autorovy disertační práce. Tyto ratingové systémy mají společné, že:

- výzkumníci pracovali se čtyřstupňovou posuzovací škálou.

- každý stupeň na škále byl většinou kvantifikován od hodnoty 4 do hodnoty 1

- každý indikátor konkrétní oblasti kvality byl pro daný stupeň slovně vymezen, dva posuzovatelé byli tedy vždy nuceni rozhodnout se bud' pozitivně (pro stupně + , ++ ), nebo negativně (pro stupně -, --) nebo pro možnost N, která byla v uvedených výzkumech charakterizována jako (a) není možné zaškrtnout; (b) nedá se posoudit.

\section{1 Škála pozorovacího nástroje}

Škála předkládaného pozorovacího nástroje a její kvantifikace (tabulka 1) vychází z rešerše odborných prací Kliemeho et al. (2008), Helmkeho et al. (2007), Seidelové et al. (2003) a Žáka (2006). Posuzovatelé byli při pozorování nuceni rozhodnout se bud' pro kladné hodnocení (pro stupně,+++ ), negativní hodnocení (pro stupně - , - -) nebo pro možnost N. 
Tabulka 1

Škála a jeji kvantifikace

\begin{tabular}{|c|c|c|c|c|}
\hline++ & + & - & -- & $\mathrm{N}$ \\
\hline 4 & 3 & 2 & 1 & 0 \\
\hline
\end{tabular}

\section{2 Škálové vymezení indikátorů kvality výuky}

Pro škálové vymezení indikátorů kvality výuky byly inspirací výzkumné práce Helmkeho et al. (2007), Seidelové et al. (2003) a Žáka (2006), ve kterých byl každý indikátor kvality pro daný stupeň škály slovně vymezen. Př́klad škálového vymezení konkrétního indikátoru $\mathrm{v}$ předkládaném pozorovacím nástroji je uveden $\mathrm{v}$ tabulce 2.

Tabulka 2

Škálové vymezeni konkrétního indikátoru v pozorovacím nástroji-přiklad

\begin{tabular}{|l|l|}
\hline \multicolumn{2}{|c|}{1.1 Učitelův zájem o předmět } \\
\hline++ & $\begin{array}{l}\text { Učitel působil ve výuce činorodě s pozitivním vztahem a zájmem o svůj předmět. Pro } \\
\text { výuku bylo typické učitelovo nadšení. }\end{array}$ \\
\hline+ & $\begin{array}{l}\text { Učitel vykazoval ve výuce částečně pozitivní vztah a zájem o svůj předmět. Pro výuku } \\
\text { ale nebylo typické učitelovo nadšení. }\end{array}$ \\
\hline- & $\begin{array}{l}\text { Učitel působil ve výuce spíše rezervovaně, zdrženlivě a chladě ve vztahu ke svému } \\
\text { předmětu. }\end{array}$ \\
\hline-- & $\begin{array}{l}\text { Učitel působil ve výuce bez zájmu, vnitřně málo zúčastněně, znuděně, rutinně, } \\
\text { nezajímavě a odmítavě. }\end{array}$ \\
\hline $\mathrm{N}$ & Nedá se posoudit. \\
\hline
\end{tabular}

\subsection{Oblasti kvality pozorovacího nástroje}

Doposud poslední varianta pozorovacího nástroje kvality výuky, která je prezentována $\mathrm{v}$ rámci tohoto článku, se vztahuje na celou vyučovací jednotku a skládá se z oblastí oborově obecných: (a) motivování; (b) klima podporujíci učení; (c) práce s časem; (d) orientace na cíle, a oblasti oborově specifické učiteli̛v projev. Tato oblast je vymezena jak pro mateřský jazyk (jasnost - mateřský jazyk), tak pro cizí jazyk (jasnost - cizí jazyk, výslovnost, jistota ve slovní zásobě, správnost gramatických tvarů, zvláštní vyjadřovací návyky). Podrobný popis oblastí včetně indikátorů dané oblasti se nachází v tabulce 3 .

Pro oblast motivování byly inspirací indikátory popsané v ratingu Žáka (2006) a Helmkeho et al. (2007). Pro oblast klimatu podporujicího učení byly inspirací indikátory definované v ratingu Helmkeho et al. (2007). Tato oblast byla během pilotáže navíc doplněna o dva relevantní indikátory kvality v dané oblasti: (a) prriměřený čas čekání na odpověd', (b) atmosféra ve výuce (viz tabulka 3 ). Tyto dva indikátory byly autorem pozorovacího nástroje vytvořeny na základě poznatků z odborné literatury (srov. Helmke, 2009, s. 220-229). Pro oblast práce $s$ časem byly inspirací indikátory ratingu Helmkeho et al. (2007). Indikátory oblasti orientace na cíle byly charakterizovány na základě části ratingu Seidelové et al. (2003). 
Tabulka 3

Pozorovací nástroj kvality výuky

\begin{tabular}{|c|c|c|}
\hline Oblast kvality výuky & \multicolumn{2}{|c|}{ Indikátory dané oblasti } \\
\hline \multirow[t]{7}{*}{ 1. Motivování } & 1.1 Učitelův zájem o předmět & \\
\hline & 1.2 Zájem žáků o výuku & \\
\hline & 1.3 Využití zájmu žáků & \\
\hline & 1.4 Propojení s praxí, životem & \\
\hline & 1.5 Povzbuzování k mluvení žáků & \\
\hline & $\begin{array}{l}\text { 1.6 Propojení výuky s jinými } \\
\text { vyučovacími předměty }\end{array}$ & \\
\hline & $\begin{array}{l}1.7 \text { Věcná a konstruktivní zpětná } \\
\text { vazba }\end{array}$ & \\
\hline \multirow[t]{7}{*}{$\begin{array}{l}\text { 2. Klima podporující } \\
\text { učení }\end{array}$} & $\begin{array}{l}2.1 \text { Učitelovo chování k žákům } \\
\text { (zájem, srdečnost, vřelost) }\end{array}$ & \\
\hline & 2.2 Humor & \\
\hline & $\begin{array}{l}2.3 \text { Učitelův pozitivní přístup } \\
\text { k chybám žáků }\end{array}$ & \\
\hline & $\begin{array}{l}\text { 2.4 Pozitivní př́ístup k chybám ze } \\
\text { strany žáků }\end{array}$ & \\
\hline & $\begin{array}{l}2.5 \text { Kultivace vztahů mezi žáky a } \\
\text { učitelem }\end{array}$ & \\
\hline & 2.6 Přiměřený čas čekání na odpověd' & \\
\hline & 2.7 Atmosféra ve výuce & \\
\hline \multirow[t]{3}{*}{ 3. Práce s časem } & 3.1 Využití času pro předmět & \\
\hline & 3.2 Plánování výuky & \\
\hline & 3.3 Nerušená výuka & \\
\hline \multirow[t]{4}{*}{ 4. Orientace na cíle } & 4.1 Oznámení cíle na začátku hodiny & \\
\hline & 4.2 Navázání na cíl v průběhu hodiny & \\
\hline & 4.3 Vysvětlení cíle v průběhu hodiny & \\
\hline & $\begin{array}{l}4.4 \text { Vysvětlení průběhu hodiny na } \\
\text { konci výuky s ohledem na cíl }\end{array}$ & \\
\hline \multirow[t]{8}{*}{ 5. Učitelův projev } & \multirow[t]{2}{*}{ 5.1 Jasnost - mateřský jazyk } & $\begin{array}{l}\text { 5.1.1 Koherence } \\
\text { učitelových výkladů } \\
\text { (obsahový aspekt) }\end{array}$ \\
\hline & & $\begin{array}{l}\text { 5.1.2 Výstižnost učitelovy } \\
\text { mluvy během výkladu } \\
\text { (jazykový aspekt) }\end{array}$ \\
\hline & \multirow[t]{2}{*}{ 5.2 Jasnost - cizí jazyk } & $\begin{array}{l}\text { 5.2.2 Koherence } \\
\text { učitelových výkladů } \\
\text { (obsahový aspekt) }\end{array}$ \\
\hline & & $\begin{array}{l}5.2 .3 \text { Výstižnost učitelovy } \\
\text { mluvy během výkladu } \\
\text { (jazykový aspekt) }\end{array}$ \\
\hline & 5.3 Výslovnost & \\
\hline & 5.4 Jistota ve slovní zásobě & \\
\hline & 5.5 Správnost gramatických tvarů & \\
\hline & 5.7 Zvláštní vyjadřovací návyky & \\
\hline
\end{tabular}

3.4 Výsledky pilotáže 
V rámci pilotáže doposud konečné verze pozorovacího nástroje bylo dvěma na sobě nezávislými pozorovateli posuzováno šest hodin videomateriálu výuky cizího jazyka. Pro ověření spolehlivosti pozorovacího nástroje výuky cizího jazyka byla zjišt'ována: (a) míra absolutní shody; (b) míra částečné shody (jde o situace, kdy jeden pozorovatel označil na stupnici možnost + a druhý ++ nebo jeden pozorovatel označil na stupnici možnost $-\mathrm{a}$ druhý --); c) pro zjištění míry inter-rater-reliability, tzn. shody mezi jednotlivými posuzovateli, byl vypočítán koeficient Cohenova Kappa (tabulka 4).

Bortz a Döring (2002, s. 277) považují za přijatelnou hodnotu Cohenovy Kappy vyšší, než 0,70. Shrneme-li výsledky pilotáže (tabulka 4), splnila doposud konečná varianta pozorovacího nástroje požadavky na inter-rater reliabilitu ve většině pozorování.

Tabulka 4

Výsledky pilotáže

\begin{tabular}{|c|c|c|c|}
\hline Hodina & $\begin{array}{c}\text { Absolutní shoda (\%) mezi } \\
\text { posuzovateli (1) a (2) }\end{array}$ & $\begin{array}{c}\text { Č́stečná shoda mezi } \\
\text { posuzovateli (1) a (2) }\end{array}$ & $\begin{array}{c}\text { Cohenova Kappa } \\
\text { posuzovatel (1) a (2) }\end{array}$ \\
\hline Zkušební A & $48 \%$ & $27 \%$ & 0,362 \\
\hline Zkušební B & $77 \%$ & $17 \%$ & 0,742 \\
\hline Zkušební C & $79 \%$ & $13 \%$ & 0,741 \\
\hline Zkušební D & $62 \%$ & $24 \%$ & 0,529 \\
\hline Zkušební E & $77 \%$ & $17 \%$ & 0,745 \\
\hline Zkušební F & $93 \%$ & $7 \%$ & 0,897 \\
\hline
\end{tabular}

\section{Závěr}

Cílem tohoto článku bylo představit: (a) cíle výzkumu; (b) přistupy výzkumu; (c) pozorovací nástroj, který bude využit při výzkumu v autorově disertační práci; (d) dosavadní výsledky pilotáže. Doposud konečná varianta pozorovacího nástroje je složena z pěti oblastí kvality výuky cizího jazyka: (a) motivování; (b) klima podporující učení; (c) práce s časem; (d) orientace na cíle; (e) učitelův projev. Zmíněné oblasti kvality výuky vycházejí ze zahraničních a domácích výzkumů a obsahují konkrétní relevantní indikátory kvality výuky. Ke každému $\mathrm{z}$ indikátorů jsou slovně vymezeny stupně škály. Pro zjištění shody mezi jednotlivými posuzovateli byl vypočítán koeficient Cohenova Kappa. Z poznatků odborné literatury (Bortz \& Döring, 2002, s. 277) vyplývá, že za přijatelnou je považována hodnota vyšší než 0,70 . Výsledky pilotáže (tabulka 4) prokazují, že doposud konečná varianta pozorovacího nástroje požadavky na inter-rater reliabilitu splnila ve většině posuzování. V rámci dalších postupů bude třeba $\mathrm{v}$ budoucnu provést několik dalších analýz videozáznamů hodin výuky cizího jazyka, které by měly vést $\mathrm{k}$ takovému vycizelování předkládaného pozorovacího nástroje cizího jazyka, aby mohl být v průběhu roku 2012 použit v rámci plánované videostudie. 


\section{Literatura}

Bortz, J., \& Döring, N. (2002). Forschungsmethoden und evaluation für human- und sozialwissenschaftler. Heidelberg: Springer.

Helmke, A., et al. (2007). Der ratingbogen der DESI-videostudie. Dostupné z http://www.unilandau.de/helmke/download/index_buch.php

Helmke, A. (2009). Unterrichtsqualität und Lehrerprofessionalisierung. Diagnose, Evaluation und verbesserung des Unterrichts. Seelze: Klett Verlag.

Hugener, I. (2006). Überblick über die Beobachtungsinstrumente. In K. Rakoczy \& Ch. Pauli (Ed.), Dokumentation der erhebungs- und auswertungsinstrumente zur schweizerisch-deutschen videostudie "Unterrichtsqualität, lernverhalten und mathematisches verständnis" (pp. 45-54). Frankfurt am Main: GFPF/DIPF.

Klieme, E. et al. (2008). Unterricht und Kompetenzerwerb in Deutsch und Englisch. Ergebnisse der DESI-Studie. Weinheim - Basel: Beltz Verlag.

Seidel, T., Prenzel, M., Duit, R., \& Lehrke, M. (2003). Technischer bericht zur videostudie „Lehrlern-prozesse im Physikunterricht. Kiel: IPN.

Starý, K., \& Chvál, M. (2009). Kvalita a efektivita výuky: metodologické př́istupy. In M. Janíková \& K. Vlčková et al., Výzkum výuky: tematické oblasti, výzkumné přistupy a metody (pp. 64-74). Brno: Paido.

Žák, V. (2006). Zjištováni parametrů kvality výuky fyziky (Disertační práce). Praha: UK v Praze.

Zlatníček, P., Ducháčková, G., Knecht, P., Najvar, P., \& Janík, T. (2010). Kvalita ve zdělávání: vymezení a systematizace pojmů. In T. Janík, P. Knecht \& P. Najvar, et al., Nástroje pro monitoring a evaluaci kvality výuky a kurikula (pp. 13-32). Brno: Paido.

Zlatníček, P., Ducháčková, G., \& Janík, T. (2010). Kvalita výuky v oborech školního vzdělávání. In T. Janík, P. Knecht \& P. Najvar, et al., Nástroje pro monitoring a evaluaci kvality výuky a kurikula (pp. 33-42). Brno: Paido.

\section{Kontakt}

Mgr. Pavel Zlatníček

Masarykova univerzita

Pedagogická fakulta, Katedra německého jazyka a literatury

Poříčí 7, 60300 Brno

e-mail: goldschmidchen@seznam.cz

\section{Bibliografické údaje}

Zlatníček, P. (2011). Kvalita výuky cizích jazyků - vývoj a pilotáž pozorovacího nástroje. In T. Janík, P. Knecht, \& S. Šebestová (Eds.), Smišený design v pedagogickém výzkumu: Sborník př́spěvki̊ z 19. výročni konference České asociace pedagogického výzkumu (s. 257-262). Brno: Masarykova univerzita.

Dostupné z: http://www.ped.muni.cz/capv2011/sbornikprispevku/zlatnicek.pdf doi: 10.5817/PdF.P210-CAPV-2012-88 